\title{
TRIAP1 wt Allele
}

National Cancer Institute

\section{Source}

National Cancer Institute. TRIAP1 wt Allele. NCI Thesaurus. Code C106455.

Human TRIAP1 wild-type allele is located in the vicinity of 12q24.31 and is approximately

$2 \mathrm{~kb}$ in length. This allele, which encodes TP53-regulated inhibitor of apoptosis 1, plays a role in the negative regulation of apoptosis. 